\title{
Implementation of X-ray Fluorescence Microscopy for Investigation of Elemental Abnormalities in Amyotrophic Lateral Sclerosis
}

\author{
B. Tomik · J. Chwiej · M. Szczerbowska-Boruchowska • \\ M. Lankosz · S. Wójcik · D. Adamek · G. Falkenberg · \\ S. Bohic $\cdot$ A. Simionovici $\cdot$ Z. Stegowski $\cdot$ A. Szczudlik
}

Accepted: 8 November 2005/Published online: 3 May 2006

(C) Springer Science+Business Media, Inc. 2006 such abnormalities were observed for the nerve cells. We also demonstrated differences in the elemental accumulation between the analyzed ALS cases.

Keywords ALS $\cdot$ Elemental analysis $\cdot$ Synchrotron radiation $\cdot$ Spinal cord section $\cdot$ Nerve cell

\section{Introduction}

Amyotrophic lateral sclerosis (ALS) is a fatal progressive neurodegenerative disorder whose typical feature is the degeneration and death of the cortical and spinal motor neurons. It occurs both sporadically (SALS) and in about $10 \%$ of the cases as a familial disease (FALS) [1]. The etiology of ALS is not known, however there are some interplaying processes that lead to degeneration and atrophy of motor neurons in this disorder. These are: excitotoxicity, aggregation and dysfunction of critical proteins, mitochondrial damage, oxidative stress, disturbances of the axonal transport and mutation of $\mathrm{Cu} / \mathrm{Zn}$ superoxide dismutase gene (Cu/Zn SOD1) [1-7]. Thus, the etiology of ALS is likely to be multifactorial [1-7]. Recent epidemiological evidences indicate that ALS occurrence is increasing in many countries. It can be the result of either environmental factors or better diagnostic criteria [8].

There is strong evidence that the trace metals carry weight in the processes leading to neurodegeneration [4, 9-11]. Metalloproteins are a special class of proteins that utilize the unique properties of metal atoms in conjunction with the macromolecular aggregates to perform life-sustaining processes [12]. The transition metal ions (i.e. iron, copper) undergoing redox reactions when present in the unbound form in the tissue play a very important role in oxidative 
stress. Metal-mediated oxidative stress may lead to several intracellular alterations and contribute to the induction of cell death pathways [13]. Copper and zinc are the components of copper-zinc superoxide dismutase type 1 (SOD1) and because of this fact they can be involved in neurodegeneration in ALS cases that proceed through this gene mutation [13, 14]. In other mechanisms leading to neurodegeneration in ALS, trace metals carry weight as well. For that reason elemental analysis, especially of metallic ones on the autopsy specimens from ALS patients seems to be essential to detect the possible anomalies. Synchrotron microbeam X-ray fluorescence techniques (micro-SRXRF) were applied for topographic and quantitative analysis of selected elements in spinal cord tissue. In this technique the analyzed material is exposed to the synchrotron beam of X-rays. The photons eject the electrons from the internal shells of atoms and cause their excitation. The excited atoms relax by emission of X-ray radiation. Because the energy of emitted radiation is characteristic for the excited atom the measured spectrum contains information about the elemental composition of the sample under investigation. On the other hand, the intensity of the emitted radiation is proportional to the content of the element in the sample, therefore the microSRXRF technique enable to carry out the quantitative analysis of materials as well. The third-generation synchrotron X-ray sources and recent progress in X-ray focusing optics make possible the collimation of photon beams down to sub-micrometer dimensions at high intensity [15]. Such beams can be successfully applied in analytical techniques using scattering, diffraction, fluorescence or absorption of X-ray radiation. The combined use of the methods based on the above mentioned phenomena may provide a comprehensive picture of the biological systems. During the last 20-30 years synchrotron radiation techniques have played an important role in structure-function studies of metalloproteins [12]. Moreover, the microSRXRF was previously satisfactory applied to elemental analysis of cultured single cells as well as thin tissue slices, including neurological applications [16-19]. Yoshida et al. [20] studied the distribution and chemical state of iron in single neurons from substantia nigra (SN) of Parkinson's patient. However, the applied sample pretreatment i.e. fixation in formalin and embedding in paraffin might change the oxidation state and the content of the elements in the tissue. Similar analyses were performed by Ide-Ektessabi et al. [21] for the samples of brain tissue from monkeys injected with MPTP (1-metyl-4-phenyl1,2,3,6-tetrahydropyridine), the compound that causes symptoms resembling Parkinson's disease. The possibilities of the use of micro-SRXRF techniques for mapping and quantitative analysis of metallic elements in neurons from brain tissues affected by Alzheimer's disease were tested by Ishihara et al. [22].

The present work is the trial of the medical interpretation of the micro-SRXRF results obtained for ALS and control spinal cord sections as described by Chwiej et al. [23].

\section{Experimental Procedure}

The samples of thoracic spinal cord were taken during routine autopsies from three patients deceased from sporadic (no positive familial history of the disease) ALS and from five patients deceased due to non-ALS conditions and representing the control group. In all ALS cases, patients died due to respiratory failure at the Neurological Department of the Jagiellonian University in Krakow and were autopsy-confirmed according to El Escorial criteria [24]. For the neuropathological examination samples were taken from all lobes of the brain hemispheres including motor cortex, basal ganglia, brain stem and three levels of spinal cord. The samples were fixed in Bouin's solution and processed routinely into paraffin blocks, then cut and stained with hematoxyline eosin and Kluver-Barrer method for myelin. Samples from motor cortex, brain stem and spinal cord were also stained immunohistochemically with antibody against ubiquitin. The histopathological examinations of spinal cord samples, in all ALS cases, showed significant loss of motor neurons. Moreover, ubiquitinpositive inclusions were found in anterior horns in all ALS spinal cords. They were usually in the form of small cytoplasmic Bunina-body-like or skein-type deposits. The control group consisted of five patients with: stroke (three patients), cerebral hemorrhage (one patient) and septic shock (one patient). In all of these cases, no pathology consistent with the criteria for ALS was found. The mean age of death was 63 years (range from 49 to 74 years) in the ALS group and 54 years (range from 32 to 69 years) in the control group. Spinal cord tissue was taken from both groups with postmortem delay time between death and sampling. This delay was equal to $20.3 \pm 2.1 \mathrm{~h}$ (mean $\pm \mathrm{SD}$ ) for ALS patients, respectively $18.6 \pm 3.3 \mathrm{~h}$ for the control group. The specimens were cut by cryomicrotome $\left(-30{ }^{\circ} \mathrm{C}\right)$ into $20 \mu \mathrm{m}$ thick slices. From each section one slice was stained with hematoxyline-eosin and served as a reference slide to enable orientation (identification of neurons) during measurements in synchrotron facility and the other one was used for measurements using the X-ray fluorescence technique. The slices dedicated for the micro-SRXRF measurements were mounted on the ultra-pure, ultra-thin and transparent for X-rays foils (AP1 or ultralene) and then freeze-dried. The element contents were investigated in the 
area of ventral horns and white matter of the thoracic spinal cord.

The synchrotron microbeam X-ray fluorescence technique was applied to the topographic and quantitative elemental analysis of the human spinal cord tissue. The measurements were performed on the bending magnet beamline L at HASYLAB (Hamburger Synchrotronstrahlungslabor) [25] and on the beamline ID 22 at ESRF (European Synchrotron Radiation Facility) [26]. A schematic view of the experimental set-up of the beamline $\mathrm{L}$ was presented in Fig. 1. The detailed description of the experimental set-up and the applied measurement conditions on the beamlines L and ID 22 was presented in papers [23] and [19], respectively. The incident photon beams with an energy of $17 \mathrm{keV}$ were applied. This beam energy enables the analysis of the elements with atomic number between $14(\mathrm{Si})$ and $38(\mathrm{Sr})$. On beamline $\mathrm{L}$ the beam was focused with polycapillary optics [27] to the size of $15 \mu \mathrm{m}$ in diameter whilst on the ID 22 with the use of parabolic compound refractive lenses [28] to a spot size of $5 \mu \mathrm{m} \times 2 \mu \mathrm{m}$ (horizontally $(\mathrm{H}) \times$ vertically $(\mathrm{V}))$. Twodimensional distributions of elements were determined. The areas selected for scanning were mapped with a step of $20 \mu \mathrm{m}$ by $20 \mu \mathrm{m}$ for the beam size of $15 \mu \mathrm{m}$ and with a step of $10 \mu \mathrm{m}(\mathrm{H})$ by $5 \mu \mathrm{m}(\mathrm{V})$ for the other one. The time of acquisition was equal to $10 \mathrm{~s}$ and $3 \mathrm{~s}$ per pixel, respectively. In both cases the measurements were carried out in the air. The characteristic X-ray lines were measured with $\mathrm{Si}(\mathrm{Li})$ detectors. For each sample, the distribution of elements was obtained by the detailed analysis of each spectrum that included the following steps:

1. background subtraction,

2. integration of the area under the peak of the $K_{\alpha}$ line corresponding to the chosen element,

3. normalization of the net peak area of the element to the incident beam flux,
4. construction of the matrix composed of the horizontal and vertical beam position on the sample and the values of the normalized net peak area of elements,

5. graphic visualization of the matrix.

\section{Results}

The following elements: $\mathrm{P}, \mathrm{S}, \mathrm{Cl}, \mathrm{K}, \mathrm{Ca}, \mathrm{Fe}, \mathrm{Cu}, \mathrm{Zn}, \mathrm{Br}$ and $\mathrm{Sr}$ were detected in ALS and control spinal cord sections. A typical spectrum excited in the tissue was shown in Fig. 2.

The results of topographic analyses performed for two selected control samples were illustrated in Figs. 3 and 4. In Fig. 3 the maps of $\mathrm{P}, \mathrm{Cl}, \mathrm{K}$ and $\mathrm{Zn}$ accumulations obtained for the area of ventral horn (with the nerve cell body) and surrounding white matter were presented. However, in Fig. 4 the distributions of $\mathrm{P}, \mathrm{Cl}, \mathrm{Ca}, \mathrm{Fe} \mathrm{Cu}, \mathrm{Zn}$ and $\mathrm{Br}$ in the motor neuron and the outside tissue in comparison with the microscopic view of the scanned area were shown. As one can notice from Fig. 3, there are the differences in elemental accumulation between nerve cells, their surrounding tissue and white matter. Additionally, excluding $\mathrm{Zn}$, white matter of the spinal cord revealed higher levels of the detected elements in respect of the ventral horns. For $\mathrm{Zn}$ an inverse relation was observed. Generally, for the control samples a higher accumulation of $\mathrm{S}, \mathrm{Cl}, \mathrm{K}, \mathrm{Ca}, \mathrm{Cu}, \mathrm{Zn}$ and $\mathrm{Br}$ was observed in the nerve cells than in the outside tissue. However, $\mathrm{P}$ and $\mathrm{Fe}$ levels in motor neurons depended on the analyzed sample, but very often a lower concentration of $\mathrm{P}$ was found there. The maps of distribution of $\mathrm{P}, \mathrm{S}, \mathrm{Ca}, \mathrm{Cu}$ and $\mathrm{Zn}$ as well as the microscopic view of an ALS (1) tissue section were shown in Fig. 5. For this ALS sample a higher accumulations of $\mathrm{Cl}, \mathrm{K}, \mathrm{Ca}, \mathrm{Zn}$ and $\mathrm{Br}$ was found in neuron bodies in comparison with the surrounding area. Moreover, the
Fig. 1 Schematic view of the experimental set-up at the beamline L (HASYLAB, Hamburg, Germany)

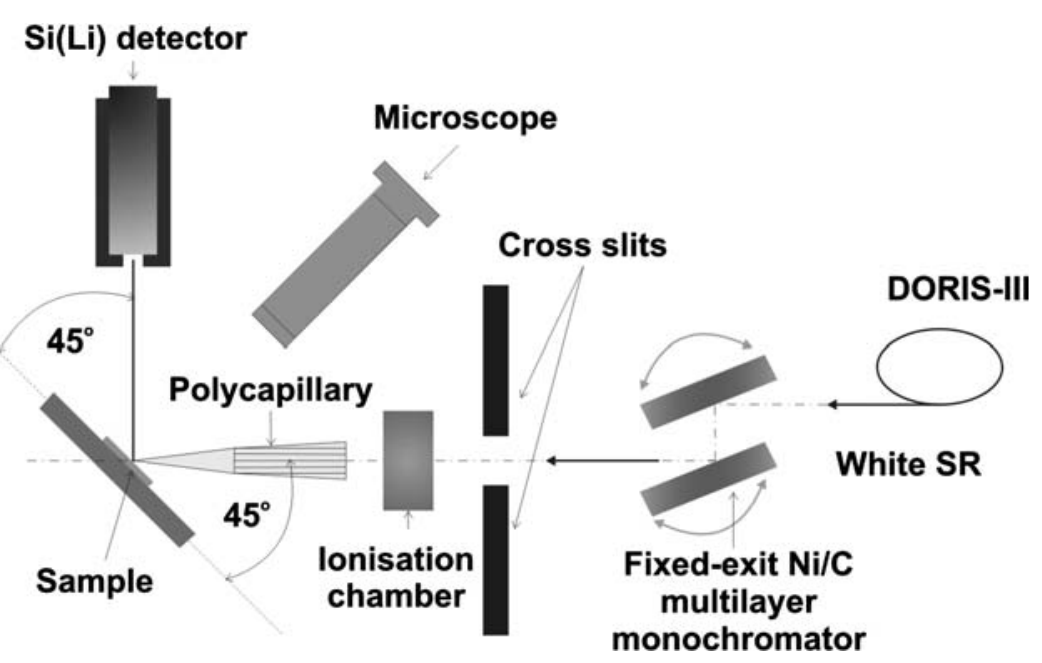


Fig. 2 The typical spectrum excited in the spinal cord tissue

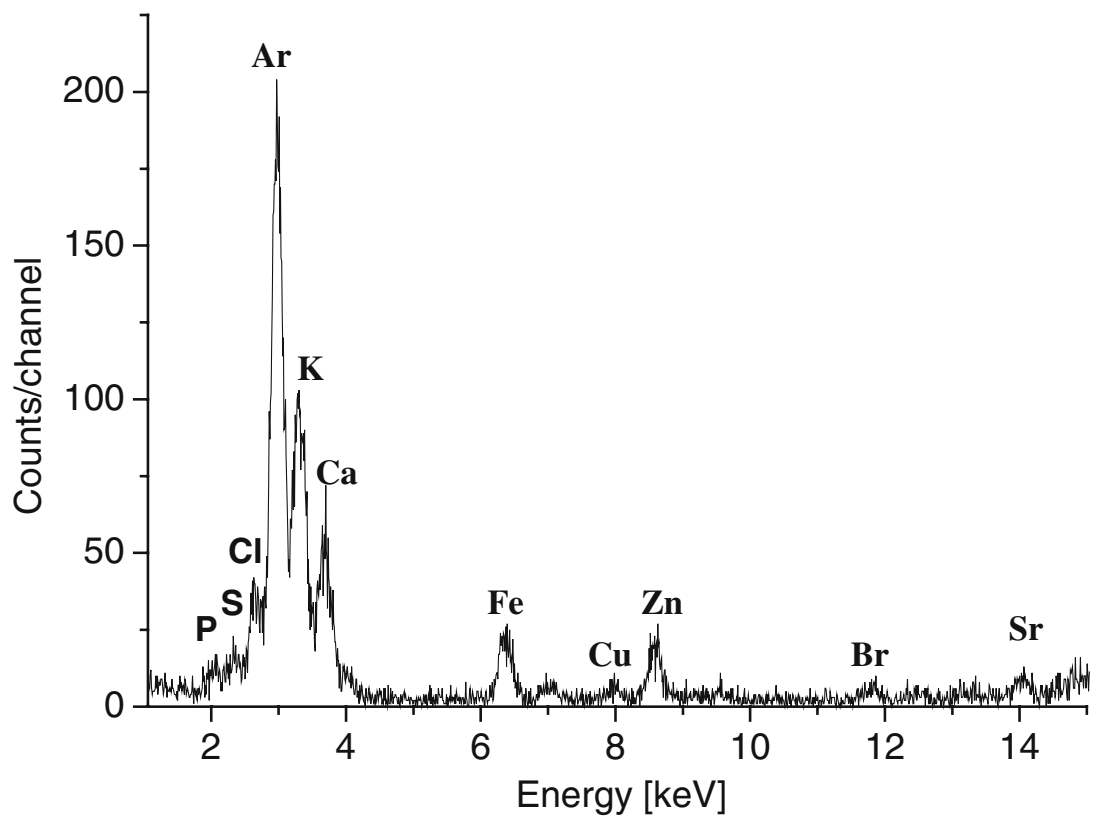

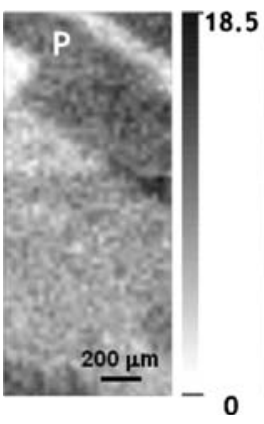
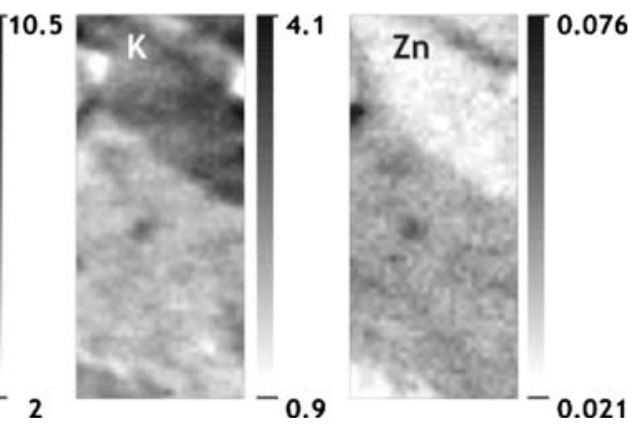

Fig. 3 Distributions of masses per unit area (in $\left.\left[\mu \mathrm{g} / \mathrm{cm}^{2}\right]\right)$ of selected elements in the spinal cord sections; 1 -nerve cell, 2 - gray matter, 3 -white matter topography of the mentioned elements clearly reflected the stage of neuronal degeneration. The intraneuronal levels of $\mathrm{P}, \mathrm{S}, \mathrm{Fe}$ and $\mathrm{Cu}$ were comparable with the outside area of the tissue.

For quantitative analysis, the masses per unit area of elements were calculated as it was presented elsewhere [23]. The detailed results of analysis on neuron bodies were summarized in Table 1 where the maximal values from the cell bodies were shown. Typically, one motor neuron was situated in the scanned area of the tissue, excluding the sample labeled as ALS (1). For this case, 5 small and degenerated nerve cells were found in the mapped tissue section. The results of quantitative analysis showed that in neurons of the control group accumulations of $\mathrm{Fe}$ and $\mathrm{Br}$ change in quite wide ranges. The maximal levels of these elements were nearly four times higher than the lowest ones. For other elements the relative differences between maximal and minimal values did not exceed $40 \%$. Moreover, the obtained results showed differences in elemental accumulation between analyzed ALS cases. The most elemental abnormalities were noticed for the sample labeled as ALS (2). In this case, a significantly higher level of $\mathrm{K}, \mathrm{Ca}, \mathrm{Fe}$ and $\mathrm{Zn}$ in the neuron body was found in comparison with the control group. For the sample marked as ALS (1) a variation of the elemental levels was noticed also between 5 neurons presented in the scanned area of the tissue. The highest variation (i.e. about 14 times between the highest and the lowest values) of the elemental accumulation was observed for $\mathrm{Zn}$. In case of the ALS (1) sample, decreased masses per unit area of $\mathrm{Cl}$ and $\mathrm{Zn}$ were observed but only for the selected neurons. For the sample ALS (3), a difference was only recorded for $\mathrm{Cu}$. The level of this element was lower than $0.004 \mu \mathrm{g} / \mathrm{cm}^{2}$, (DL for $\mathrm{Cu}$ ) whereas for the control neurons the $\mathrm{Cu}$ level changed from $0.0072 \pm 0.0005 \mu \mathrm{g} /$ $\mathrm{cm}^{2}$ to $0.0084 \pm 0.0006 \mu \mathrm{g} / \mathrm{cm}^{2}$.

For the areas of white matter the mean values were calculated from 36 measurement points (taken from an area of about $200 \mu \mathrm{m} \times 200 \mu \mathrm{m})$. The results obtained were graphically presented in Fig. 6. In this area of the spinal cord, no significant differences were noticed between pathological and control tissues. This suggests that the 
Fig. 4 Distributions of masses per unit area (in $\mu \mathrm{g} / \mathrm{cm}^{2}$ ) of selected elements in the control spinal cord sections in comparison with the microscopic view of the scanned area (the arrow shows the neuron body)
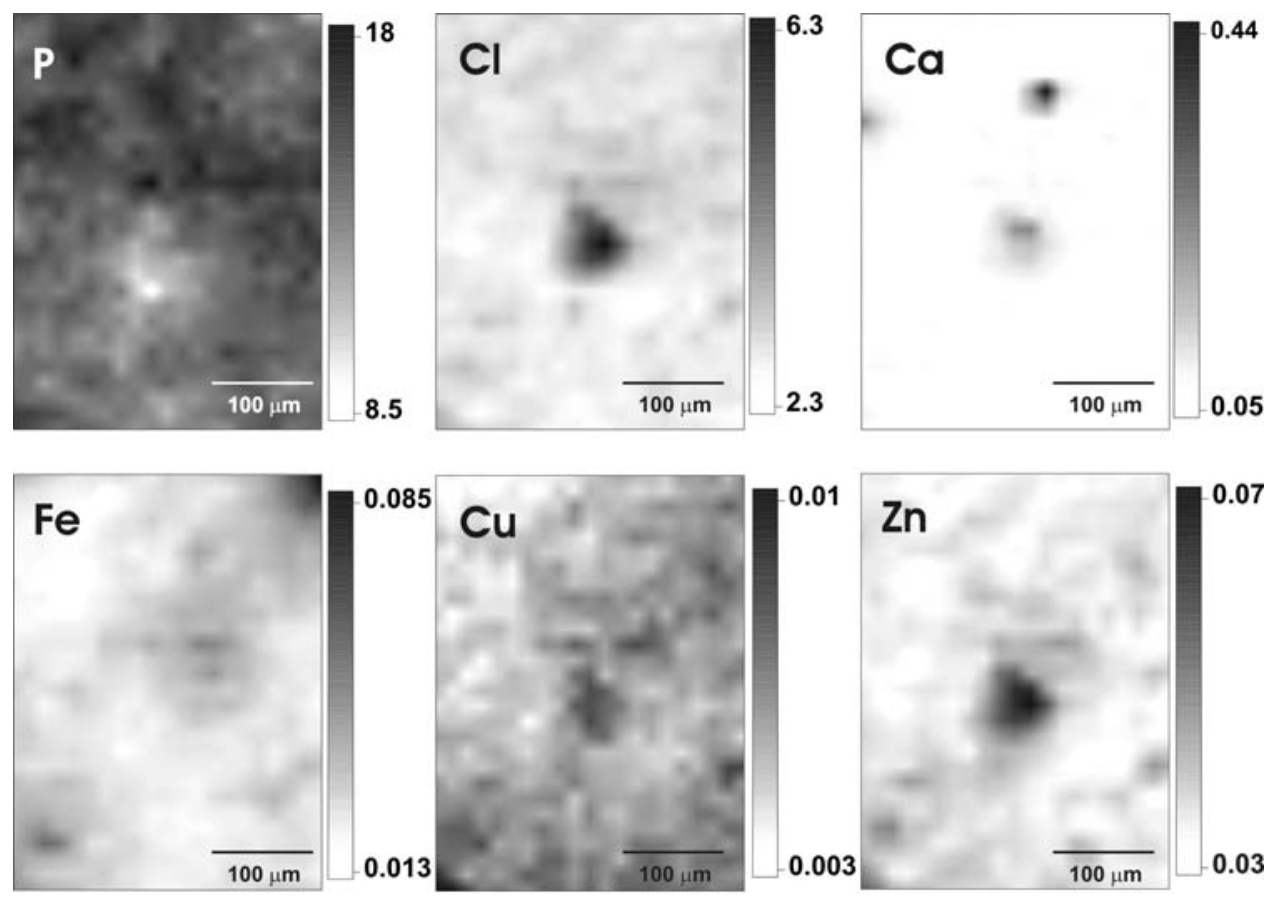

0.085
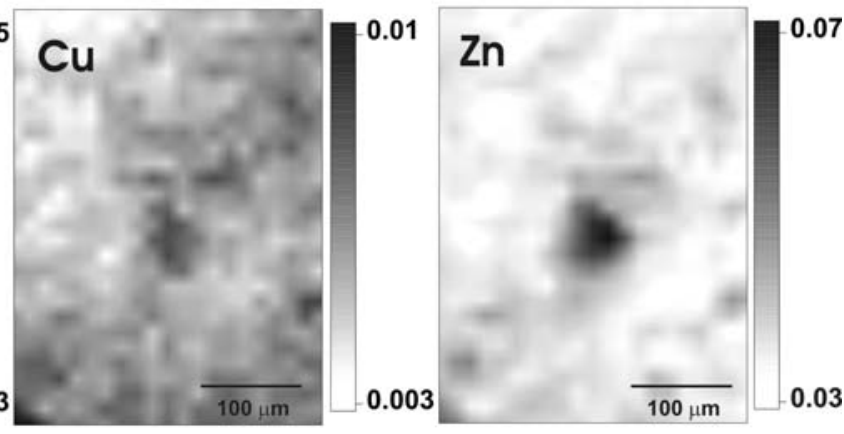
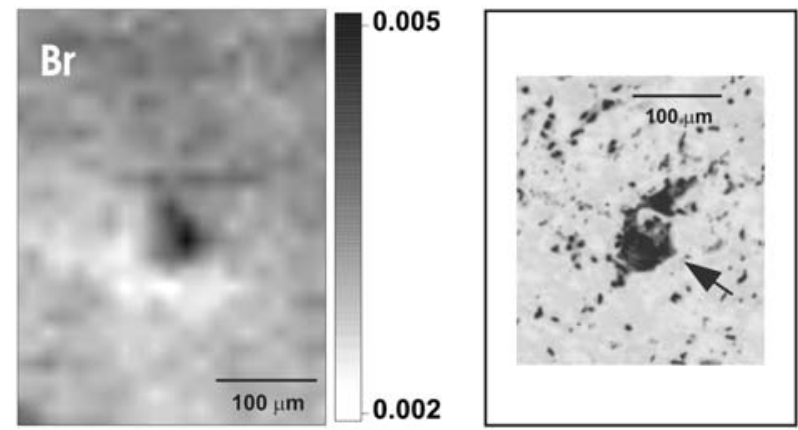

changes of the elemental distribution affect rather the gray matter.

The analytical capability of the methods used can be described by the minimal detection limits (MDL) of elements. The minimal detection limit of an element is the lowest level that can be determined by a selected analytical procedure. For spinal cord tissue, calculations of these values were performed for the polycapillary focused photon beam (most of the results were obtained using this method), in the typical measurement conditions and with the use of the expression given by Currie [29]. The results obtained were presented in the Table 2.

\section{Discussion}

The growing number of publications point that metallochemical reactions and abnormal distributions of the trace metals in the central nervous system tissue might be the common denominators underlying neurodegenerative diseases such as: ALS, Parkinson disease, Alzheimer disease, prion disease. Trace elements have been implicated in the pathogenesis of the ALS for a long time. Because the new evidence has connected familial ALS with the metalloenzyme copper-zinc-manganese superoxide dismutases, the studies of their metabolism are being reinforced now [30]. In the central nervous system, zinc is highly localized in the cerebral cortex and hippocampus [31]. Because $\mathrm{Zn}$ is found in CNS at synapses, co-localized with glutamate in presynaptic terminals, it is supposed to be a powerful modulator of both excitatory synaptic transmission and glutamate-related currents at physiologically relevant concentrations [31, 32]. Zinc plays a role both in normal functioning of the brain and in the pathophysiology of neurodegenerative disorders [33]. It is known that zinc ions act as key modulators of the neuronal activity and death through the mechanisms involving the production of free radicals [34]. Most of the $\mathrm{Zn}$ ions in the brain are bound to 
Fig. 5 Distributions of selected elements in the ALS (1) spinal cord sections in comparison with the microscopic view of the scanned area (the arrows show neurons localization)
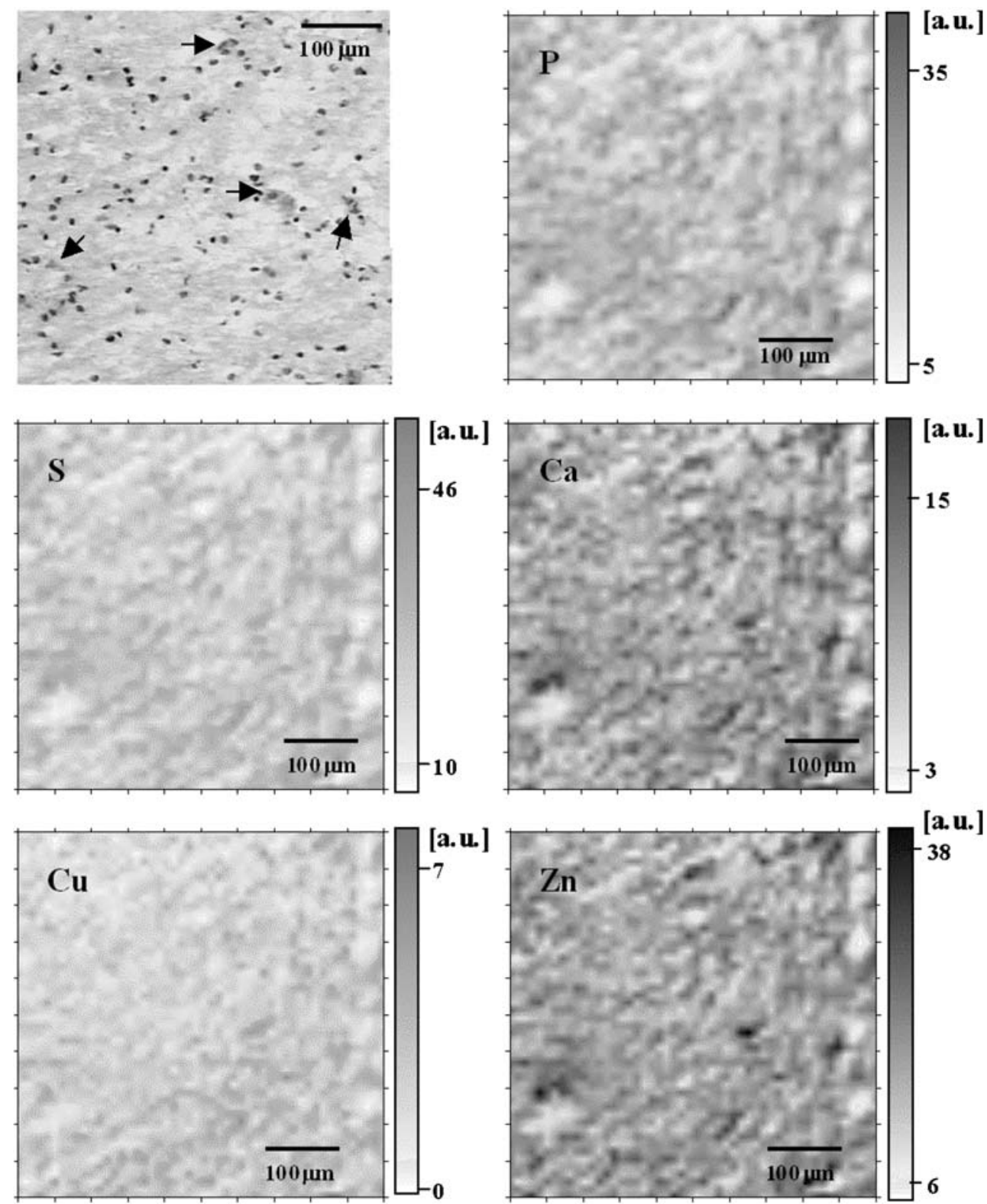

metalloproteins and amino acids within the neuron cytoplasm [35]. In spite of lack of redox activity of the zinc ions, the disruption of intracellular homeostasis of this element may participate in oxidative stress by interfering with mitochondrial metabolism and generation of mitochondrial reactive oxygen spaces [36]. However, observed alterations in zinc accumulation inside neuron pericarial parts can also be a result of oxidative stress-mediated reactions in cells that cause liberation of zinc ions from metallothioneins [37]. On the other side, since $\mathrm{Zn}$ is a component of $\mathrm{Cu}-\mathrm{Zn}$ superoxide dismutase, an important factor of antioxidant defense [2], the observed increased level of $\mathrm{Zn}$ in ALS (case 3) motor neuron may indicate intensified reactions against superoxide radicals. Moreover, the abnormalities of $\mathrm{Zn}$-protein associations may be involved in the promotion of protein aggregation [11] and by this way in the death of the neurons. Zinc is necessary for DNA replication and transcription as well as to the protein synthesis [38]. The abnormal accumulation of $\mathrm{Zn}$ inside the nerve cell observed in the present studies could suggest that it may interfere with the genetic machinery of the cell. In order to elucidate if the source of the abnormalities found is nucleolar or cytoplasmatic, an analysis with better spatial resolution is required. In case of ALS (1) a lower level of $\mathrm{Zn}$ was found in neurons. It may suggest a diminished catalytic activity of Zn-deficient SOD that was previously observed as a neurotoxic for cultured cells [39].

Copper is also an essential trace element that serves as a cofactor in a number of oxygen-processing enzymes involved in diverse metabolic processes. Its redox reactivity 
Table 1 The maximal masses per unit area of elements in the spinal cord motor neurons

\begin{tabular}{|c|c|c|c|c|}
\hline \multirow[t]{2}{*}{ Elements } & \multicolumn{4}{|l|}{ Mass per unit area $\left[\mu \mathrm{g} / \mathrm{cm}^{2}\right]$} \\
\hline & Control Group $^{a}$ & $\operatorname{ALS}(1)^{b}$ & ALS (2) & ALS (3) \\
\hline $\mathrm{P}$ & $13.0(0.9)^{\mathrm{d}}-15(1)$ & $7.8(0.5)-21(1)$ & $20(1)$ & $8.9(0.6)$ \\
\hline S & $4.9(0.3)-6.1(0.4)$ & $3.1(0.2)-5.9(0.4)$ & $4.0(0.3)$ & $3.7(0.2)$ \\
\hline $\mathrm{Cl}$ & $6.4(0.4)-9.6(0.6)$ & $3.9(0.2)-9.3(0.6)$ & $5.6(0.3)$ & $7.0(0.4)$ \\
\hline K & $3.7(0.2)-6.0(0.4)$ & $3.4(0.2)-6.2(0.4)$ & $11.2(0.7)$ & $3.9(0.2)$ \\
\hline $\mathrm{Ca}$ & $0.24(0.01)-0.36(0.02)$ & $0.18(0.01)-0.39(0.02)$ & $17(1)$ & $0.44(0.03)$ \\
\hline $\mathrm{Fe}$ & $0.029(0.002)-0.101(0.006)$ & $0.033(0.002)-0.055(0.003)$ & $1.6(0.1)$ & $0.092(0.006)$ \\
\hline $\mathrm{Cu}$ & $0.0072(0.0005)-0.0084(0.0006)$ & $0.0053(0.0004)-0.0071(0.0005)$ & $0.0070(0.0005)$ & $<\mathrm{MDL}^{\mathrm{c}}$ \\
\hline $\mathrm{Zn}$ & $0.063(0.004)-0.081(0.005)$ & $0.0050(0.0003)-0.071(0.004)$ & $0.18(0.01)$ & $0.068(0.004)$ \\
\hline $\mathrm{Br}$ & $0.0051(0.0003)-0.020(0.001)$ & $0.0054(0.0003)-0.019(0.001)$ & $0.0080(0.0005)$ & $0.020(0.001)$ \\
\hline
\end{tabular}

${ }^{a}$ Data obtained for five cases

${ }^{\mathrm{b}}$ Data obtained for five neurons

${ }^{\mathrm{c}}$ Below minimal detection limit

${ }^{\mathrm{d}}$ The data in the parentheses represent uncertainty of the masses per unit area of elements

leads to the risk of damage of the cells and tissues. It was also suggested that neuronal deficiency of $\mathrm{Cu}$ can cause the degeneration of nerve cells $[13,40,41]$. The observed decreased levels of $\mathrm{Cu}$ inside the ALS (3) neuron may reflect dysfunctions of the copper-dependent enzymes such us mitochondrial cytochrom $c$ oxidase, $\mathrm{Cu}-\mathrm{Zn}$ superoxide dismutase or celuroplasmin. According to the existing hypothesis, the degeneration and atrophy of neurons may be the result of protein aggregation or damage caused by $\mathrm{Cu}$-catalysed reactions [11]. On the other side, since copper complexes may also work against oxidative damage [42] the lower accumulation of this element inside neuron pericarial parts could reflect diminished antioxidant reaction.

The most cited neurodegenerative role of $\mathrm{Fe}$ is its participation in generation of free radicals in the Fenton reaction [43]. The increased level of Fe in ALS (2) motor neuron can confirm this putative mechanism of cell death. However, at the present time it is not possible to state if the neuron atrophy was caused by oxidative damage or by any other mechanisms such us mitochondrial dysfunction or protein damage that can also be catalyzed by Fe ions.

As mentioned previously, in the nerve cell from the ALS (2) sample, increased levels of $\mathrm{Ca}$ were found. Calcium is well-known factor in the mechanism of cell death [44]. Intracellular influx of $\mathrm{Ca}$ may result (among many other sequels) in the improper function of mitochondrium [45]. This may be linked to apoptosis. It is known that calcium dyshomeostasis may lead to apoptotic cell death mainly by disruption of the activity of Ca-dependent enzymes or mitochondrial dysfunction [46].

Mn toxicity induces parkinsonism in humans and has been associated with ALS-PD syndrome [30]. $\mathrm{Zn}, \mathrm{Cu}$ and Mn play a crucial role in the activity of $\mathrm{Cu} / \mathrm{Zn}$ SOD1, an enzyme that catalyses the conversion of toxic superoxide radicals to hydrogen peroxide and oxygen. Superoxide dismutases are the major antioxidant enzymes involved in free radical scavenging. A copper atom at the active site mediates catalysis [14]. Mutations in SOD1 may cause oxidative damage by impairing the ability of the enzyme to bind to zinc. Deprived of zinc, both mutant and wild-type SOD1 are less efficient superoxide scavengers, and the rate of tyrosine nitrition increases. Mutations in SOD1 that impair the antioxidant functions of the enzyme could lead to the toxic accumulation of superoxide radicals resulting in the degeneration of motor neurons [14, 40]. Bergomi et al. [47] have reported that the level of $\mathrm{Cu}$ in left foot toenails of ALS patients, measured by inductively coupled plasma optical spectrometry, tends to increase with the progression of the disease. This can result from the abnormal metabolism of SOD1 or metalloproteins [13, 48].

It was suggested that upon mutation, SOD1 is partially misfolded and improperly binds copper leading to oxidative stress and to induction of cell death [4]. Whereas SOD1 is the cytosolic isoenzyme inactivating superoxide radicals, manganese superoxide dismutase (SOD2) is the equivalent mitochondrial isoenzyme [8]. Shaw et al. [49] have reported an increased proportion of SOD activity due to SOD2 in ALS tissue from the thoracic anterior horn. It was reported by Tomblyn et al. [50] that several ALS patients have been identified with variants in the targeting sequence of the mitochondrial form of SOD. Liu et al. [51] have documented the increased brainstem motor neuronal SOD2, as well as SOD1 immunoreactivity. Thus, the metals may take a part in triggering an acceleration of oxidative stress in the motor neurons in cases of ALS. However, the results of studies on their role are still conflicting.

It is also well known that trace element status can be easily modified by environmental exposure, disease status, nutrition, age and other demographic factors which can influence the results of the cited studies [47]. In spite of the 
Fig. 6 Masses per unit area of elements determined in white matter of ALS and control (c) spinal cord sections
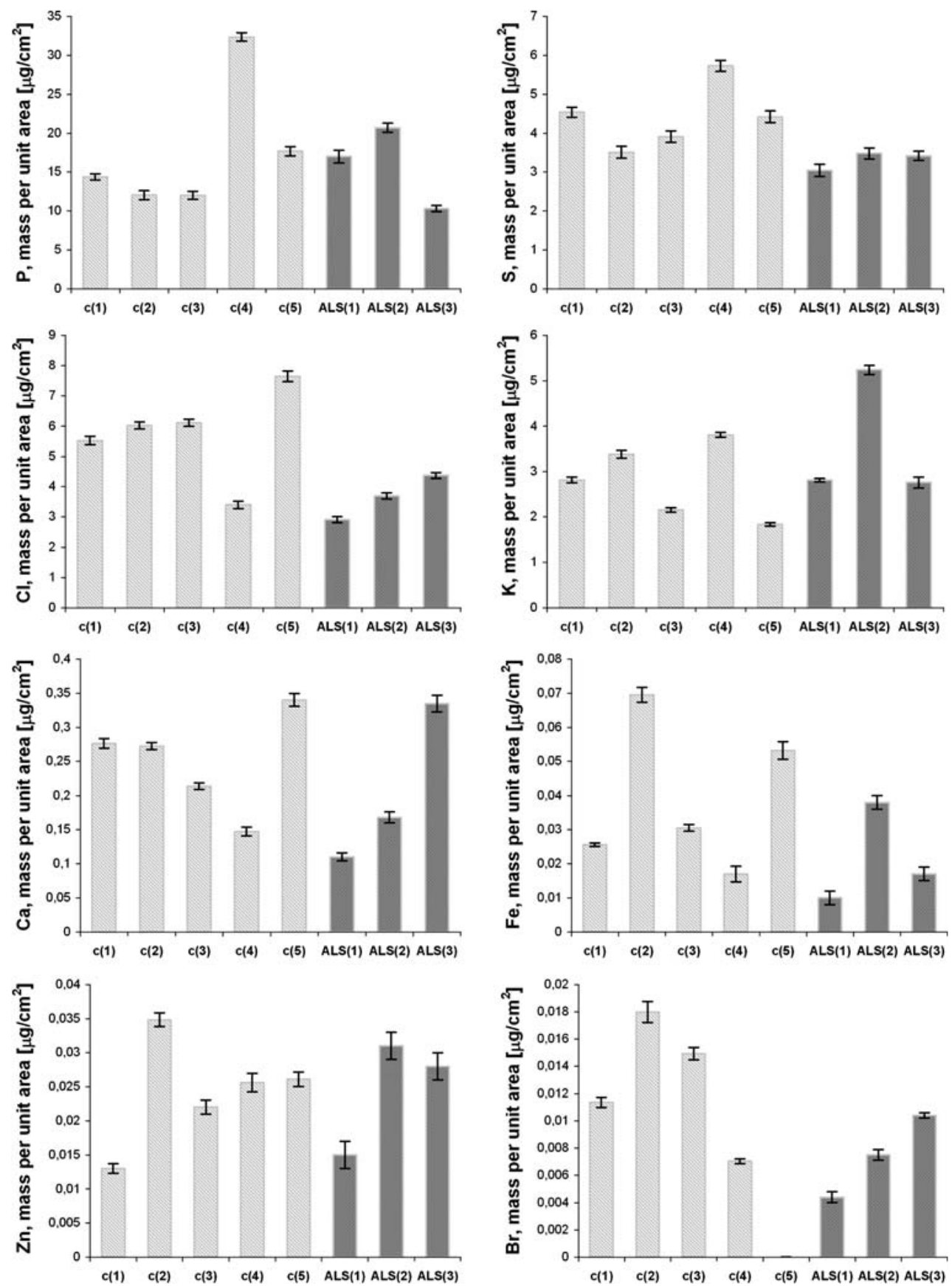

above-mentioned data, the relationship between the trace elements and the ALS pathogenesis is still obscure.

It is difficult to clarify the meaning of our results in the light of the literature. It has been shown that the metal homeostasis may be altered in different human biological materials (liquids and tissues) from ALS patients but the results are contradictory [52]. Kanias and Kapaki [53] reported statistically significant differences between older control (age $>40$ years) and ALS patients (age $<40$ years) for $\mathrm{Cu}$ in cerebrospinal fluid (CSF) and serum, for $\mathrm{Mn}$ in serum and for $\mathrm{Zn}$ in CSF. Dysmetabolism of $\mathrm{Zn}$ was also reported for ALS patients in spinal cord and blood. Zn was found to be either unchanged, decreased, or increased [52, 54-56]. Kapaki et al. [30] has found decreased levels of $\mathrm{Cu}$ in CSF, whilst $\mathrm{Zn}, \mathrm{Mn}$ and $\mathrm{Mg}$ levels were unchanged. Moreover, the authors have found lower $\mathrm{Cu}$ and higher $\mathrm{Mn}$ serum levels in 28 ALS patients. However, Torsdottir et al.'s [57] and Pamphlett et al.'s [52] studies have not showed differences in the $\mathrm{Cu}$ plasma concentrations that are dependent on the disease status. Kasarskis et al. [58] used the laser microprobe mass spectrometry (LMMS) for analysis of accumulation of trace metals in neuronal 
Table 2 The minimal detection limits (MDL) of elements for the spinal cord tissue sections

\begin{tabular}{ll}
\hline Element & MDL $\left[\mu \mathrm{g} / \mathrm{cm}^{2}\right]$ \\
\hline $\mathrm{P}$ & 1.3 \\
$\mathrm{~S}$ & 0.4 \\
$\mathrm{Cl}$ & 0.2 \\
$\mathrm{~K}$ & 0.1 \\
$\mathrm{Ca}$ & 0.04 \\
$\mathrm{Fe}$ & 0.006 \\
$\mathrm{Cu}$ & 0.004 \\
$\mathrm{Zn}$ & 0.004 \\
$\mathrm{Br}$ & 0.002 \\
\hline
\end{tabular}

cytoplasm, nucleus, capillaries and neuropil in samples of ventral cervical spinal cord from five ALS and five control cases. They reported that $\mathrm{Al}$ was not altered in any area of the ALS samples, however Fe and $\mathrm{Ca}$ were $1.5 \div 2$ times higher in the nucleus and cytoplasm of ALS neurons but unchanged in capillaries and neuropils in comparison with the controls. The elevated Fe level inside spinal neurons may be important in the pathogenesis of ALS. This element may induce the degeneration of motor neurons by catalyzing Fenton's reaction and leading to the overproduction of reactive oxygen species [59]. The increased level of Fe in the spinal cord of ALS patients was described by Ince et al. [60] and Markesbery et al. [56]. However, these results were in contradiction with the ones obtained by Khare et al. [55]. Kurlander and Patten [54] found that in the anterior horn tissue the iron content was higher $(P<0.05)$ in seven ALS patients than in 11 controls with neurological and non-neurological diseases. Nagata et al. [61] showed that the Mn concentrations in blood cells from ALS patients were significantly lower than from controls (nonALS subjects). On the other hand, Kihira et al. [62] with the use of the Inductively Coupled Plasma (ICP) spectroscopy, discovered that the mean content of $\mathrm{Mn}$ in the spinal cord was similar for ALS (0.39 microgram/g wet weight in the anterior horn, 0.37 in the lateral fasciculus, 0.39 in the posterior horn and 0.28 in the posterior fasciculus) and control subjects but the distribution of this element differed. In case of ALS, the content of Mn was higher in the anterior horn and lateral fascicules than in the posterior horn. Different data were presented by Ejima et al. [63] who studied the concentrations of Mn, Se, Fe and Zn, by inductively coupled plasma-mass spectrometry (ICP-MS), in the spinal cord of four controls and a patient with ALS. The only element that revealed higher concentrations for the ALS patient was Mn. In other works, both increased and decreased Mn levels in the spinal cord were found in ALS patients [55, $64,65]$. On the other hand the blood levels of Mn were unchanged in Pamphlett et al.'s [52] studies.

Calcium has also been studied in relation to the pathogenesis of ALS [8] and results show that excitotoxicity and antibodies against calcium channel might be involved in the etiology of ALS. Yanagihara et al. [66] have demonstrated radiological features of the demineralization in $10 \%$ of 16 Guamanian Chamorros studied. Intestinal absorption of calcium, as assessed by serum and urinary activity of calcium 47 following oral administration, was decreased in two patients with ALS and also in four patients with parkinsonism-dementia, all of whom had low levels of serum 1,25-dihydroxyvitamin D. Reductions in the cortical bone mass were striking in patients with motor neuron disease [66]. Increased spinal cord calcium concentrations were reported in 6 out of 16 cases of Guamanian ALS [67]. Additionally, $\mathrm{Ca}$ has been found in hippocampal neurofibrillary tangles in Guamanian ALS patients [68] but not in classical ALS [54]. Moreover, it is known that chronic dietary deficiency (since birth) in $\mathrm{Ca}$, $\mathrm{Mg}$ and $\mathrm{Zn}$ induces excessive absorption of divalent cations which accelerate oxidant-mediated neuronal degeneration in a genetically susceptible population. The process is probably caused by interactions between a cytoskeletal abnormality of the neuron, the ageing process, the abnormal proteins and the mitochondrial dysfunction [69]. Epidemiological studies of endemic foci of ALS at the Kii Penisula and Guam have shown chronically low concentrations of $\mathrm{Ca}, \mathrm{Mg}$ and high concentrations of $\mathrm{Al}$ and $\mathrm{Mn}$ in garden soil and drinking water. It was hypothesized that chronically low concentrations of $\mathrm{Ca} / \mathrm{Mg}$ in food enhance the absorption of $\mathrm{Al}$ from the gastrointestinal tract and induce deposition of $\mathrm{Al}$ with $\mathrm{Ca}$ in the central nervous system, causing neuronal vulnerability and/or degeneration in Kii-ALS [62].

In our studies, we focused on the assessment of the levels of trace elements in ALS autopsy material. We observed the differences in trace elements accumulation between nerve cells, their surroundings and areas of white matter. Zinc, contrary to all other detected elements showed a lower level in the area of white matter. Moreover, in all analyzed samples, higher accumulations of $\mathrm{Ca}, \mathrm{Zn}, \mathrm{Cl}, \mathrm{K}, \mathrm{Br}$ were observed in the nerve cells than in the surrounding tissue. The results of quantitative analysis did not show any significant differences between ALS and the control group. Unfortunately, for both groups, the $\mathrm{Cu}$ levels in the area of white matter were below the detection limit of this element. Additionally, we noticed the differences in elemental accumulation between the analyzed ALS cases. Such results may be the effect of different stadium of nerve cell degeneration for the analyzed ALS cases. It is also important to take into account the fact that ALS is clinically, pathogenetically and pathologically heterogeneous, which means that causes, symptoms and pathological picture may differ [70].

A few potential limitations of the current study should be mentioned. Firstly, we have examined only a few cases from each studied groups. Difficulties with the collection of spinal cord samples from ALS patients as well as from others may underlie the differences, at least to some degree. Secondly, 
because of the methodological differences, we do not have a real opportunity to directly compare our results to data from other sources. The synchrotron microbeam X-ray fluorescence technique (micro-SRXRF) is rarely used for topographic and quantitative analysis of selected elements in the spinal cord tissues taken from patients with neurodegenerative diseases, especially ALS. Thus, we hope that our results can be the first step for future research in this area.

Acknowledgements The authors are grateful to the Ministry of Education and Science, State Committee for Scientific Research grant 112/E-356/SPB/DESY/P-05/DWM728/2003-2005 and IHP-Contract HPRI-CT-1999-00040/2001-00140 of the European Commission. Thanks are also due to The European Community-Research Infrastructure Action under FP6 "Structuring the European Research Area" Programme (through the Integrated Infrastructure Initiative

"Integrating Activity on Synchrotron and Free Electron Laser Science") and Experimental grants: HASYLAB II-02-092 and ESRF LS 2111.

\section{References}

1. Menzies FM, Ince PG, Shaw PJ (2002) Mitochondrial involvement in amyotrophic lateral sclerosis. Neurochem Int 40:543-551

2. Cassarino DS, Bennett JP (1999) An evaluation of the role of mitochondria in neurodegenerative diseases: mitochondrial mutations and oxidative pathology, protective nuclear responses, and cell death in neurodegeneration. Brain Res Rev 29:1-25

3. Bains JS, Shaw CA (1997) Neurodegenerative disorders in humans: the role of glutathione in oxidative stress-mediated neuronal death. Brain Res. Rev 25:335-358

4. Carri MT, Ferri A, Cozzolino M, Calabrese L, Rotilio G (2003) Neurodegeneration in amyotrophic lateral sclerosis: the role of oxidative stress and altered homeostasis of metals. Brain Res Bull 61:365-374

5. Carri MT, Ferri A, Battistoni A, Famhy L, Gabbianelli R, Poccia F, Rotilio G (1997) Exspression of a Cu, Zn superoxide dismutase typical of familial amyotrophic lateral sclerosis induces mitochondrial alteration and increase of cytosolic $\mathrm{Ca}^{2+}$ concentration in transfected neuroblastoma SH-SY5Y cells. FEBS Lett 414: 365-368

6. Kruman II, Pedersen WA, Springer JE, Mattson MP (1999) ALSlinked $\mathrm{Cu} / \mathrm{Zn}$-SOD mutation increases vulnerability of motor neurons to excitotoxicity by a mechanisms involving increased oxidative stress and perturbed calcium homeostasis. Exp Neurol 160:28-39

7. Orrell RW (2000) Amyotrophic lateral sclerosis: copper/zinc superoxide dismutase (SOD1) gene mutations. Neuromuscular Dis 10:63-68

8. Mitchell JD (2000) Amyotrophic lateral sclerosis: toxins and environment Amyotroph. Lateral Scler Other Motor Neuron Disord 1(4):235-250

9. Campbell A, Smith MA, Sayre LM, Bondy SC, Perry G (2001) Mechanisms by which metals promote events connected to neurodegenerative diseases. Brain Res Bull 55/2:125-132

10. Waggoner DJ, Bartnikas TB, Gitlin JD (1999) The role of copper in neurodegenerative disease. Neurobiol Dis 6:221-230

11. Bush AI (2000) Metals and neuroscience. Curr Op Chem Biol 4:184-191

12. Hasnain SS (2004) Synchrotron techniques for metalloproteins and human disease in post genome era. J Synchrotron Radit $1: 7-11$
13. Carri MT, Battistoni A, Ferri A (1994) A study of the dual role of copper in superoxide dismutase as antioxidant and pro-oxidant in cellular models of amyotrophic lateral sclerosis. Adv Exp Med Biol 448:205-213

14. Rowland LP, Shneider NA (2001) Amyotrophic lateral sclerosis. N Engl J Med 344(22):1688-1700

15. Iida A (2000) Instrumentation for $\mu$-XRF at synchrotron sources. In: Janssens KHA, Adams FCV, Rindby A (eds), Microscopic XRay Fluorescence Analysis, John Wiley, Chichester, pp 117-153

16. Bohic S, Simionovici A, Ortega R, Heymann D, Schroer C, Snigirev A (2001) Synchrotron-induced X-ray microfluorescence on single cells. Nucl Instr Meth B 181(1):728-733(6)

17. Huang YY, Lu JX, He RG, Zhao LM, Wang ZG, He W, Zhang YX (2001) Study of human bone tumor slice by SRXRF microprobe. Nucl Instrum Meth Phys Res A 467-468:1301-1304

18. Ortega R, Deves G, Fayard B, Salome M, Susini J (2003) Combination of synchrotron radiation $\mathrm{X}$-ray microprobe and nuclear microprobe for chromium and chromium oxidation states quantitative mapping in single cells. Nucl Instrum Meth Phys Res B 210:325-329

19. Szczerbowska-Boruchowska M, Lankosz M, Ostachowicz J, Adamek D, Krygowska-Wajs A, Tomik B, Szczudlik A, Simionovici A, Bohic S (2004) Topographic and quantitative microanalysis of human central nervous system tissue using synchrotron radiation. X-ray Spectrom 33(1):3-11

20. Yoshida S, Ektessabi A, Fujisawa S (2001) XAFS spectroscopy of a single neuron from a patient with Parkinson's disease. J Synchrotron Radiat 8:998-1000

21. Ide-Ektessabi A, Kawakami T, Watt F (2004) Distribution and chemical state analysis of iron in the Parkinsonian substantia nigra using synchrotron radiation micro beams. Nucl Instrum Meth Phys Res B 213:590-594

22. Ishihara R, Ide-Ektessabi A, Ikeda K, Mizuno Y, Fujisawa S, Takeuchi T, Ohta T (2002) Investigation of cellular metallic elements in single neurons of human brain tissues. Neuroreport 13(14): $1817-1820$

23. Chwiej J, Szczerbowska-Boruchowska M, Wojcik S, Lankosz M, Chlebda M, Adamek D, Tomik B, Setkowicz Z, Falkenberg G, Stegowski Z, Szczudlik A (2005) Implementation of X-ray fluorescence microscopy for investigation of elemental abnormalities in central nervous system tissue. J Alloy Compd 401(1-2):184-188

24. Brooks BR (1994) El Escorial World Federation of Neurology criteria for the diagnosis of amyotrophic lateral sclerosis. Subcommittee on Motor Neuron Diseases/Amyotrophic Lateral Sclerosis of the World Federation of Neurology Research Group on Neuromuscular Diseases and the El Escorial "Clinical limits of amyotrophic lateral sclerosis" workshop contributors. J Neurol Sci 124(Suppl.):96-107

25. Falkenberg G, Rickers K (2002) Pink-beam and monochromatic micro-X-ray fluorescence analysis at the beamline L. In: Krell U, Schneider JR, von Zimmerman M (Eds) Hasylab Annual Report 2002 Part I, HASYLAB at DESY, Hamburg, pp 88-95

26. Simionovici AS, Chukalina M, Schroer CG, Drakopoulos M, Snigirev AA, Snigireva II, Lengeler B, Janssens K, Adams F (2000) High-resolution X-ray fluorescence microtomography of homogeneous samples. IEEE Trans Nucl Sci 47:2736-2740

27. Bilderback DH, Hoffman SA, Thiel DJ (1994) Nanometer spatial-resolution achieved in hard X-ray-imaging and Laue diffraction experiments. Science 263:201-203

28. Lengeler B, Schroer CG, Tuemmler J, Benner B, Richwin M, Snigirev A, Snigireva I, Drakopoulos M (1999) Imaging by parabolic refractive lenses in the hard X-ray range. J Synchrotron Radiat 6:1153-1167

29. Currie LA (1968) Limits for qualitative detection and quantitative determination. Anal Chem 40:586-593 
30. Kapaki E, Zournas C, Kanias G, Zambelis T, Kakami A, Papageorgiou C (1997) Essential trace element alterations in amyotrophic lateral sclerosis. J Neurol Sci 147(2):171-175

31. Lin DD, Cohen AS, Coulter DA (2001) Zinc-induced augmentation of excitatory synaptic currents and glutamate receptor responses in hippocampal CA3 neurons. J Neurophysiol 85(3):1185-1196

32. Choi DW, Koh JY (1998) Zinc and brain injury. Ann Rev Neurosci 21:347-375

33. Frederickson CJ, Koh JY, Bush AJ (2005) The neurobiology of zinc in health and disease. Nat Rev Neurosci 6:449-462

34. Eom SJ, Kim EY, Lee JE, Kang HJ, Shim J, Kim SU, Gwag BJ, Choi EJ (2001) $\mathrm{Zn}(2+)$ induces stimulation of the c-Jun N-terminal kinase signaling pathway through phosphoinositide 3-Kinase. Mol Pharmacol 59(5):981-986

35. Mann DMA, Yates PO (1974) Lipoprotein pigments - their relationship to ageing in the human nervous system II. The melanin content of pigmented nerve cells. Brain 97:489-498

36. Weiss JH, Sensi SL (2000) $\mathrm{Ca}^{2+}$ permeable AMPA/kainate channels and selective neurodegeneration. Trends Neurosci 23:365-371

37. Frederickson CJ (1989) Neurobiology of zinc and zinc-containingneurons. Int Rev Neurobiol 31:145-238

38. Coleman JE (1992) Zinc proteins: enzymes, storage proteins, transcription factors, and replication proteins. Ann Rev Biochem 61:897-946

39. Estevez AG, Crow JP, Sampson JB, Reiter C, Zhuang Y, Richardson GJ, Tarpey MM, Barbeito L, Beckman JS (1999) Induction of nitric oxide-dependent apoptosis in motor neurons by zinc-deficient superoxide dismutase. Science 286:24982500

40. Rotilio G, Carri MT, Rossi L, Ciriolo MR (2000) Copperdependent oxidative stress and neurodegeneration. IUBMB Life 50(4-5):309-314

41. Silahtaroglu AN, Brondum-Nielsen K, Gredal O, Werdelin L, Panas M, Petersen MB, Tommerup N, Tümer Z (2002) Human CCS gene: genomic organization and exclusion as a candidate for amyotrophic lateral sclerosis (ALS). BMC Genet 3(1):5

42. Linder MC (2001) Copper and genomic stability. Mutation Res 475:141-152

43. Ross BM, Moszczynska A, Ehrlich J, Kish SJ (1998) Low activity of key phospholipid catabolic and anabolic enzymes in human substantia nigra: possible implications for Parkinson's disease. Neuroscience 83:791-798

44. Siesjo BK (1981) Cell damage in the brain: A speculative synthesis. J Cereb Blood Flow Metab 1:155-185

45. Kristian T, Siesjo BK (1996) Calcium related damage in ischemia. Life Sci 59:357-367

46. Yu SP, Canzoniero LMT, Choi DW (2001) Iron homeostasis and apoptosis. Curr Opin Cell Biol 13:405-411

47. Bergomi M, Vinceti M, Nacci G, Pietrini V, Bratter P, Alber D, Ferrari A, Vescovi L, Guidetti D, Sola P, Malagu S, Aramini C, Vivoli G (2002) Environmental exposure to trace elements and risk of amyotrophic lateral sclerosis: a population-based casecontrol study. Environ Res 89(2):116-123

48. Nagano S, Satoh M, Sumi H (2001) Reduction of metallothioneins promotes the disease expression of familial amyotrophic lateral sclerosis mice in a dose-dependent manner. Eur J Neurosci 13(7):1363-1370

49. Shaw IC, Fitzmaurice PS, Mitchell JD, Lynch PG (1995) Studies on cellular free radical protection mechanisms in the anterior horn from patients with amyotrophic lateral sclerosis. Neurodegeneration 4(4):391-396

50. Tomblyn M, Kasarskis EJ, Xu Y, St Clair DK (1998) Distribution of MnSOD polymorphisms in sporadic ALS patients. J Mol Neurosci 10(1):65-66
51. Liu Y, Brooks BR, Taniguchi N, Hartmann HA (1998) CuZnSOD and MnSOD immunoreactivity in brain stem motor neurons from amyotrophic lateral sclerosis patients. Acta Neuropathol (Berl) 95(1):63-70

52. Pamphlett R, McQuilty R, Zarkos K (2001) Blood levels of toxic and essential metals in motor neuron disease. Neurotoxicology 22(3):401-410

53. Kanias GD, Kapaki E (1997) Trace elements, age, and sex in amyotrophic lateral sclerosis disease. Biol Trace Elem Res 56(2):187-201

54. Kurlander HM, Patten BM (1979) Metals in spinal cord tissue of patients dying of motor neuron disease. Ann Neurol 6(1):21-24

55. Khare SS, Ehmann WD, Kasarskis EJ, Markesbery WR (1990) Trace element imbalances in amyotrophic lateral sclerosis. Neurotoxicology 11(3):521-532

56. Markesbery WR, Ehmann WD, Candy JM (1995) Neutron activation analysis of trace elements in motor neuron disease spinal cord. Neurodegeneration 4(4):383-390

57. Torsdottir G, Kristinsson J, Gudmundsson G, Snaedal J, Johannesson T (2000) Copper, ceruloplasmin and superoxide dismutase (SOD) in amyotrophic lateral sclerosis. Pharmacol. Toxicol. 87(3):126-130

58. Kasarskis EJ, Tandon L, Lovell MA, Ehmann WD (1995) Aluminum, calcium, and iron in the spinal cord of patients with sporadic amyotrophic lateral sclerosis using laser microprobe mass spectroscopy: a preliminary study. J Neurol Sci 130(2):203208

59. Valko M, Morris H, Cronin MT (2005) Metals, toxicity and oxidative stress. Curr Med Chem 12(10):1161-1208

60. Ince PG, Shaw PJ, Candy JM, Mantle D, Ehmann W, Markesbury W (1994) Iron, selenium and glutathione peroxidase activity are elevated in sporadic motor neuron disease. Neurosci Lett 182(1):87-90

61. Nagata H, Miyata S, Nakamura S, Kameyama M, Katsui Y (1985) Heavy metal concentrations in blood cells in patients with amyotrophic lateral sclerosis. J Neurol Sci 67(2):173-178

62. Kihira T, Mukoyama M, Ando K, Yase Y, Yasui M (1990) Determination of manganese concentrations in the spinal cords from amyotrophic lateral sclerosis patients by inductively coupled plasma emission spectroscopy. J Neurol Sci 98(2-3):251-258

63. Ejima A, Watanabe C, Koyama H, Satoh H (1996) Analysis of trace elements in the central nerve tissues with inductively coupled plasma-mass spectrometry. Tohoku J Exp Med 178(1):1-10

64. Miyata S, Nakamura S, Nagata H, Kameyama M (1983) Increased manganese level in spinal cords of amyotrophic lateral sclerosis determined by radiochemical neutron activation analysis. J Neurol Sci 61(2):283-293

65. Mitchell JD, East BW, Harris IA (1986) Trace elements in the spinal cord and other tissues in motor neuron disease. J Neurol Neurosurg Psych 49(2):211-215

66. Yanagihara R, Garruto RM, Gajdusek DC, Tomita A, Uchikawa T, Konagaya Y, Chen KM, Sobue I, Plato CC, Gibbs CJ (1984) Calcium and vitamin D metabolism in Guamanian Chamorros with amyotrophic lateral sclerosis and parkinsonism-dementia. Ann Neurol 15(1):42-48

67. Garruto RM, Swyt C, Fiori CE, Yanagihara R, Gajdusek DC (1985) Intraneuronal deposition of calcium and aluminium in amyotropic lateral sclerosis of Guam. Lancet 2(8468): 1353

68. Kjellin KG (1967) The CSF iron in patients with neurological diseases. Acta Neurol Scand 43(3):299-313

69. Chen KM (1995) Disappearance of ALS from Guam: implications for exogenous causes. Rinsho Shinkeigaku 35(12):1549-1553

70. Adamek D, Tomik B, Pichór A, Kałuża J, Szczudlik A (2002) Heterogeneity of neuropathological changes in ALS. The review of own autopsy material. Folia Neuropathologica 40:119-124 